\title{
Assessment of canal centering ability and topography of three nickel- titanium rotary systems
}

\section{Avaliação da centralização do preparo e da topografia de três sistemas rotatórios de níquel-titânio}

\author{
Marília Ostermann Bürgel \\ Patrícia Maria Poli Kopper** \\ Vânia Regina Camargo Fontanella** \\ Roberta Kochenborger Scarparo ${ }^{* * * *}$ \\ José Antonio Poli de Figueiredo ${ }^{* * * *}$ \\ Renata Dornelles Morgental ${ }^{* * * * *}$ \\ Fabiana Vieira Vier-Pelisser ${ }^{* * * *}$
}

\section{Abstract}

Objective: This study aimed to evaluate the canal centering ability and topography of BioRaCe $e^{T M}(B R)$, Wizard CD Plus ${ }^{T M}$ (WP), and Wizard Navigator ${ }^{T M}(W N)$ instruments. Materials and method: mesiobuccal roots of upper first molars were selected and randomly distributed in three groups $(n=10)$, according to the rotary system used for instrumentation. Canal transportation was assessed at 2, 4, 6, and $8 \mathrm{~mm}$ from the root apex, by subtracting cone bean computed tomography $(C B C T)$ images taken before and after preparation. The root canal center was marked in pre- and post-preparation images, and the distance between these points was measured in bucco-palatal (BP) and mesio-distal $(\mathrm{MD})$ directions. New instruments were analyzed under scanning electron microscopy (SEM) regarding their surface finishing, topographical features, and surface defects. The SEM images were obtained at the tip of the instrument, and at $5 \mathrm{~mm}$ from the tip. Data of the canal centering ability were analyzed by two-way ANOVA ( $\alpha$ $=0.05)$. Results: regardless of root level $(2,4,6$, and 8 $\mathrm{mm})$, all groups presented canal transportation in both directions. Significant differences were not detected ( $p$ $>0.05$ ). Surface finishing was regular in the $B R$ group with rounded transitional angle. Cutting edges had a sharp angle in BR and WN groups, while WP instru- ments had a flattened angle. Conclusion: despite such topographical differences between the rotary instruments tested, none of them were able to exactly maintain the original root canal center, and no significant differences were observed among groups.

Keywords: Root canal preparation. Endodontics. Scanning electronic microscopy. Rotary instruments.

\section{Introduction}

Appropriate cleaning and shaping are essential for successful root canal therapy ${ }^{1,2}$, as they create room for the action of irrigating solutions and intracanal medications in order to combat bacteria and their byproducts. Transportation may be defined as some undesired deviation of the original root canal lumen ${ }^{3}$, and it can result in inadequate cleaning and adversely affect treatment prognosis. A centered enlargement allows the maintenance of the initial root canal shape, providing more efficient disinfection while avoiding root perforations ${ }^{4-7}$.

MS, Post-graduate Program, School of Dentistry, Pontifical Catholic University of Rio Grande do Sul (PUCRS), Porto Alegre, RS, Brazil.

PhD, Professor, Department of Conservative Dentistry, Post-graduate Program, School of Dentistry, Federal University of Rio Grande do Sul (UFRGS), Porto Alegre, RS, Brazil.

PhD, Professor, Department of Oral Radiology, Graduate Program, School of Dentistry, Brazilian Lutheran University (ULBRA), Canoas, RS, Brazil.

**** PhD, Professor, Department of Endodontics, Post-graduate Program, School of Dentistry, Pontifical Catholic University of Rio Grande do Sul (PUCRS), Porto Alegre, RS, Brazil.

$* * * *$ PhD, Post-doctoral student, Department of Endodontics, Post-graduate Program, School of Dentistry, Pontifical Catholic University of Rio Grande do Sul (PUCRS), Porto Alegre, RS, Brazil. 
The introduction of nickel-titanium (NiTi) instruments opened up new perspectives in Endodontics, since their superelasticity contributes to a more centered preparation along the root canal walls in comparison to stainless steel hand instruments $^{6,8,9}$. Nevertheless, ideal instruments are still desired, and wide ranges of NiTi rotary systems are constantly being developed.

On the other hand, the continuous use of NiTi instruments may cause deformation in their metal structure $^{10}$, which may contribute to inadequate preparation, resulting in insufficient sanitization of the root canal system. Additionally, the presence of surface defects in endodontic instruments may contribute to their fracture ${ }^{11}$.

Wizard CD Plus ${ }^{\mathrm{TM}}$ (WP) and Wizard Navigator $^{\mathrm{TM}}(\mathrm{WN})$ are recently introduced NiTi rotary systems, which present instruments with ISO-sized tips (ISO 3630-1:2008). Each system offers file sequences with different tapers, i.e., .02 to .14 for WP, and .04 to .07 for WN instruments. BioRaCe ${ }^{\mathrm{TM}}(\mathrm{BR})$ has the same physical characteristics as the former RaCe system; however, they differ in taper, instrumentation sequence, and handle configuration. BR has shown satisfactory results in the preparation of curved root canals ${ }^{12}$.

Furthermore, these instruments present differences in their design and surface. BR instruments receive an electropolishing surface treatment ${ }^{12-15}$, in order to remove machining defects, while WP and WN instruments are not submitted to any surface treatment.

Although these features, as well as instrument surface defects, may greatly affect the canal centering ability, there are few studies on the ability of BR and WP instruments to avoid canal transportation $^{12,16}$, whereas WN systems have yet to be studied.

Thus, the present study aimed to assess the canal centering ability of BR, WP, and WN instruments, while associating this feature with instrument characteristics observed by SEM.

\section{Materials and method}

The present study was approved by the Institutional Ethics and Research Committees (11/05622) of the Pontifical Catholic University of Rio Grande do Sul (PUCRS).

Thirty upper first molars were selected and radiographed using a direct digital system (CCD Cygnus Ray MPS; Progeny, Buffalo Grove, USA). Teeth presenting endodontic manipulation, incomplete root formation, calcifications and/or root resorption were excluded. The maximum degree of mesiobuccal canal curvature and their positions were determined as previously reported ${ }^{17,18}$. In the majority of samples, canals showed curvatures between $25^{\circ}$ and $35^{\circ}$ (ranging from $0.5^{\circ}$ to $58.1^{\circ}$ ), each starting between 6 and $7 \mathrm{~mm}$ from the apex (apical distance ranging from 3.96 to $14.35 \mathrm{~mm}$ ).

Teeth were randomly stratified into three groups $(n=10)$, considering variations in canal anatomy. Distribution was performed according to the rotary system employed for preparation: $\mathrm{BioRaCe}^{\mathrm{TM}}$ - BR (FKG Dentaire, Les Chaux-de-Fonds, Switzerland), Wizard CD Plus ${ }^{\mathrm{TM}}$ - WP (Medin, NovéMěsto at Moravě, Czech Republic) or Wizard Navigator ${ }^{\mathrm{TM}}$ WN (Medin, NovéMěsto at Moravě, Czech Republic). Ten sets of each system were used, thus establishing a single use for the NiTi files. Prior to preparation, the mesiobuccal roots were sectioned at their cementoenamel junction, using a high-speed diamond bur (KG Sorensen, Cotia, Brazil) under water-cooling.

\section{Canal Preparation}

The working length (WL) was visually established. A size \#10 K-file (Dentsply-Maillefer, Ballaigues, Switzerland) was inserted into the root canal until its tip was visible at the apical foramen. The WL was determined by reducing $1 \mathrm{~mm}$ from the total length, and recorded. It was set between 15 and $17 \mathrm{~mm}$ in all samples. A single trained operator performed canal instrumentations for all groups. Sizes \#10 and \#15 hand files were used throughout the WL. Then, NiTi rotary systems were used with a pecking motion. At each change of instrument, the canals were irrigated with $2 \mathrm{~mL}$ of $1 \% \mathrm{NaOCl}$ (Biodinâmica Quimica e Farmaceutica Ltda, Ibiporã, Brazil). The order in which instruments were used, their speeds, and torque are shown in Table 1.

Table 1 - Instruments sequence, speed, and torque used for canal preparation

\begin{tabular}{|c|c|c|c|}
\hline Group & BR & WP & WN \\
\hline Speed & $600 \mathrm{rpm}$ & $250 \mathrm{rpm}$ & $250 \mathrm{rpm}$ \\
\hline Torque & Maximum & $0.2-3$ N.cm & $1.2-2.3$ N.cm \\
\hline \multirow[t]{13}{*}{ Sequence } & $25.08^{q}$ & $30.08^{\S}$ & $25.07^{\S}$ \\
\hline & $15 \mathrm{~K}-$ file $^{+}$ & 15 K-file ${ }^{\dagger}$ & $15 \mathrm{~K}-$ file $^{\dagger}$ \\
\hline & $15.05^{+}$ & $25.10^{\S}$ & $30.06^{\S}$ \\
\hline & $25.04^{+}$ & $15 \mathrm{~K}-$ file $^{\dagger}$ & $15 \mathrm{~K}-$ file $^{\dagger}$ \\
\hline & $25.06^{+}$ & $30.06^{\S}$ & $25.06^{\S}$ \\
\hline & $35.04^{+}$ & 15 K-file ${ }^{\dagger}$ & $15 \mathrm{~K}-$ file $^{\dagger}$ \\
\hline & $40.04^{+}$ & $25.04^{\S}$ & $20.06^{+}$ \\
\hline & & $20.04^{+}$ & $15.05^{+}$ \\
\hline & & $20.02^{+}$ & $10.04^{+}$ \\
\hline & & $20.04^{+}$ & $15.05^{+}$ \\
\hline & & $25.04^{+}$ & $20.06^{+}$ \\
\hline & & $30.06^{+}$ & $25.06^{+}$ \\
\hline & & & $30.06^{+}$ \\
\hline
\end{tabular}

$\S$ As far as it penetrates; $\uparrow$ at the $\mathrm{WL} ;$ I at $12 \mathrm{~mm}$ 


\section{CBCT}

Canal transportation was assessed by subtracting CBCT images taken before and after instrumentation. The specimens were fitted into a Fox scale (Bio Art Equipamentos Odontológicos, São Carlos, Brazil) and adapted to a Cone Beam I - Cat tomograph (Imaging Sciences International Inc., Hatfield, USA), operated at $120 \mathrm{kV}$, and $46.72 \mathrm{~mA}$. Images were captured in a small field of view $(6 \mathrm{~cm})$ using exposure time of $40 \mathrm{~s}$, and voxel size of $0.2 \times$ $0.2 \times 0.2 \mathrm{~mm}$. Xoran - Cat software (Imaging Sciences International Inc., Hatfield, USA) was used for image reconstruction. Slices in the axial direction generated DICOM format archives ${ }^{19}$.

\section{Measurements of canal transportation}

A single blinded and calibrated examiner performed centering ability analysis. Images of the axial sections corresponding to $2,4,6$, and $8 \mathrm{~mm}$ from the apex were transferred to Adobe Photoshop program (version CS3; Adobe Systems Inc, San Jose, USA). At each section, pre- and post-preparation images corresponding to the canal center were marked. While marking the center region, one parallel line was drawn at the root canal limits (mesial, distal, buccal, and palatal). Next, measurements were made in the BP and MD directions, and the intersection between the two measures was marked. Captured images were overlapped through the subtraction technique (Fig. 1A), and the distance between the two points was measured in both BP and MD directions (Fig. 1B-D). The closer to zero the measure was, the more centered the canal preparation ${ }^{5}$.

\section{SEM analysis}

New instruments were washed in ultrasonic vat (Cristófoli, Campo Mourão, Brazil), packed in surgical grade paper (Descapark, Sao Paulo, Brazil), and sterilized by autoclaving (Dabi Atlante, Ribeirão Preto, Brazil). All instruments were then examined under a Philips XL 30 microscope (Eindhoven, North Brabant, Netherlands) at their tips, and at $5 \mathrm{~mm}$ from it, at $\times 100$ magnification. A single blinded and calibrated examiner analyzed the images to verify the surface finishing of these instruments, as well as topographical features and surface defects. Data obtained was descriptively analyzed.

\section{Statistical analysis}

Measures of centering ability were analyzed using two-way ANOVA. The significance level was set at $5 \%$.

\section{Results}

Canal transportation occurred in all groups, but significant differences were not detected (Fig. 1E$\mathrm{F})$, regardless the apical distance $(2,4,6$ and $8 \mathrm{~mm})$ and canal direction $(p>.05)$ (Fig. 1).

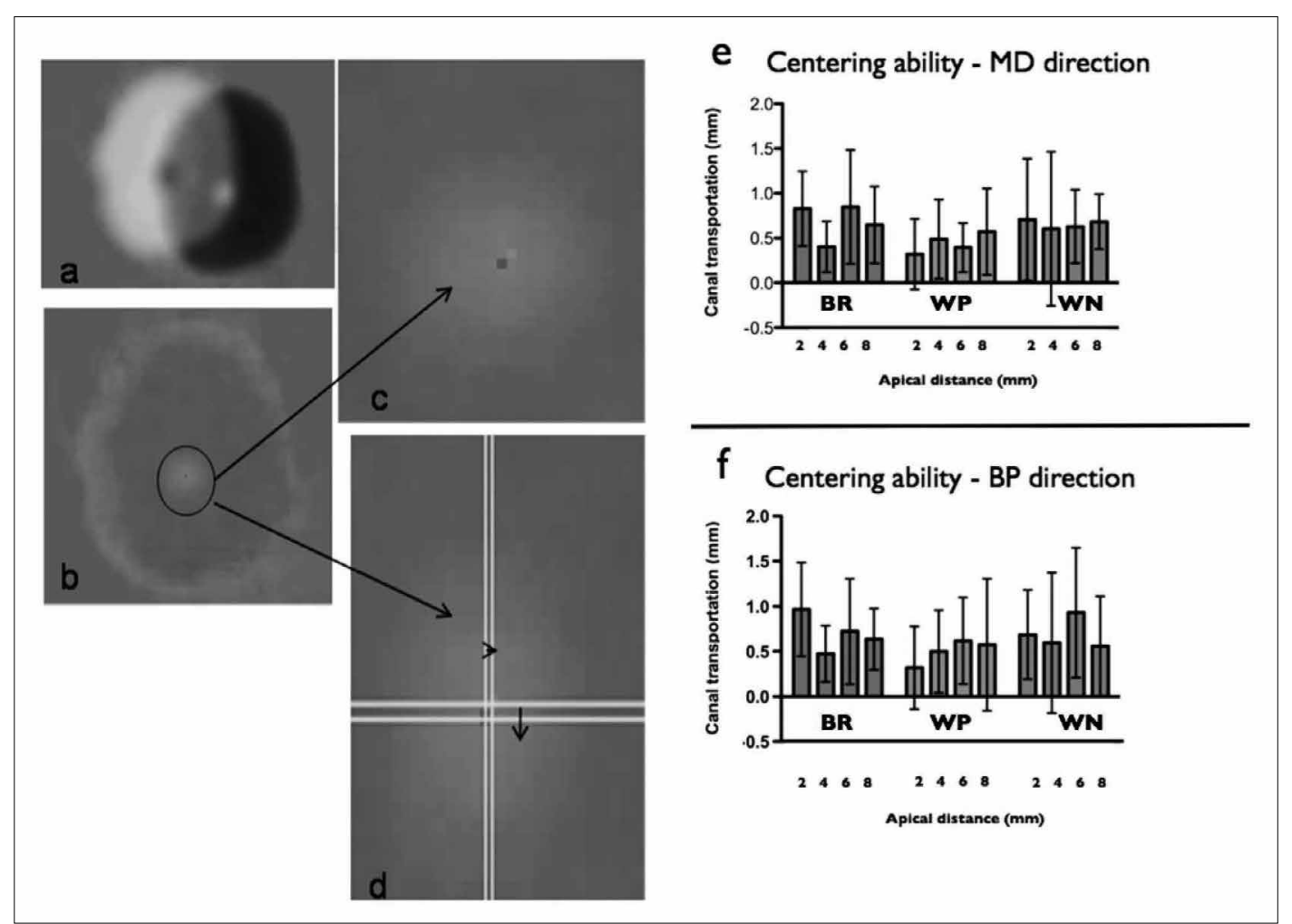

Figure 1 - Methodology used for measuring centering ability. (a) Pre and post-instrumentation images were overlapped by subtraction technique; (b-c) The central position of the root canal was marked prior (dark gray dot) and post-preparation (light gray dot); (d) Canal transportation was measured in bucco-palatal (BP) and mesio-distal (MD) directions (arrows); (e-f) Graph (Box Plot) showing the centering ability at the $M D$ and $B P$ direction 
The analysis of SEM images showed that BR instruments presented rounded tip, transitional angle, and surface finishing that was regular and polished. The cutting edges had a sharp angle. WP instruments showed a transitional angle, although the tip had a more abrupt edge. Surface finishing was irregular and the cutting edges had a flattened angle. WN instruments had an abrupt transition from the instrument shank to its tip, the surface finishing was irregular, and the cutting edges had a sharp angle (Fig. 2).
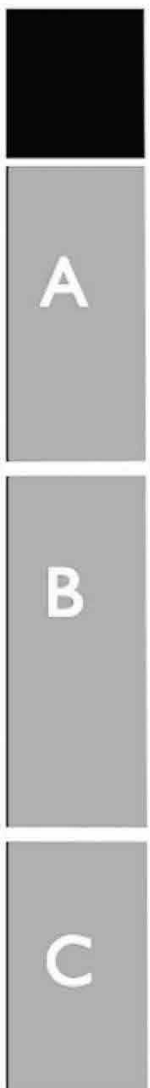
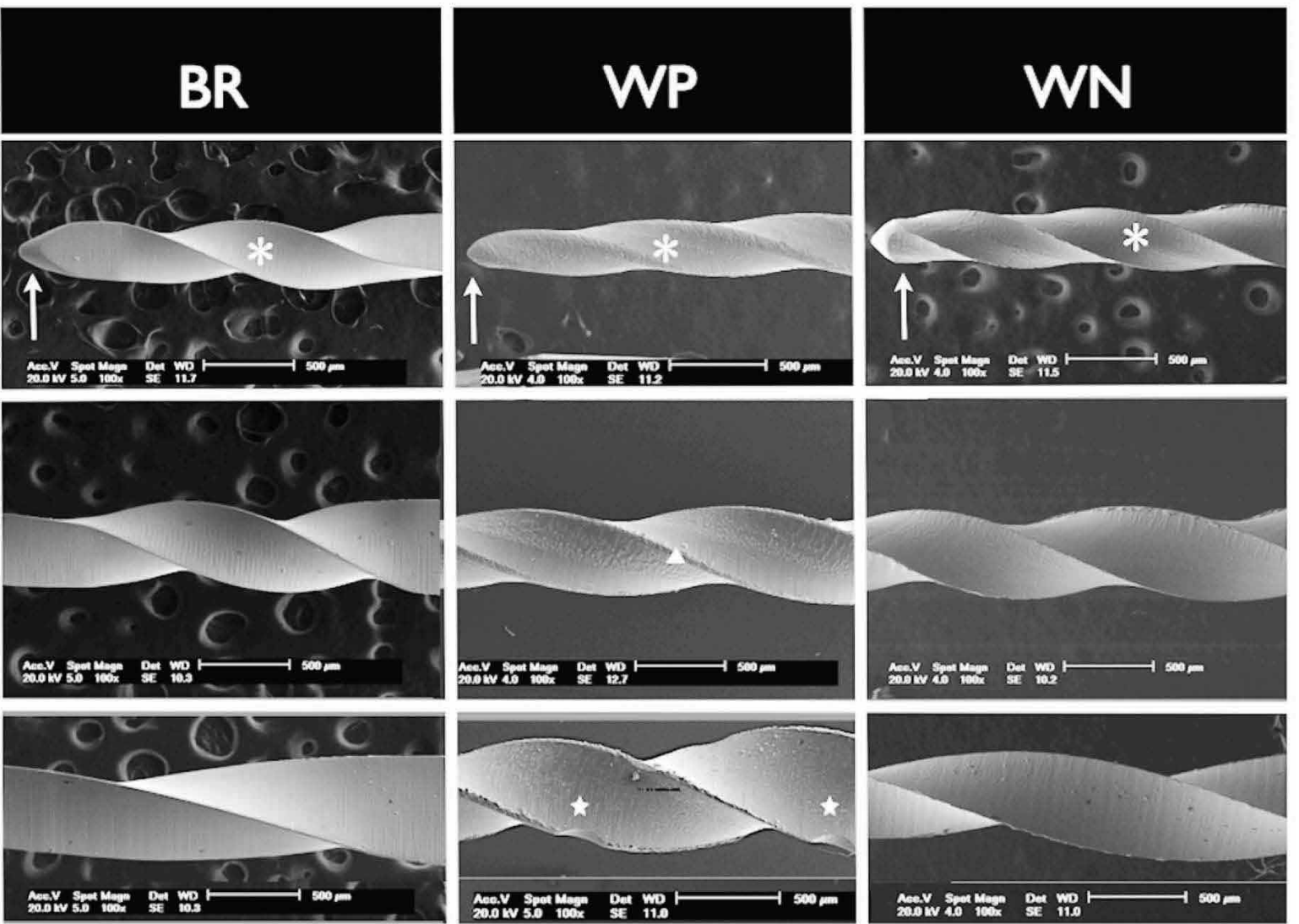

Figure 2 - Instruments surface under SEM. (A) 25.08 BR instrument showing round tip and transitional angle. 30.08 WP file presenting a transitional angle, although the tip had a more abrupt outline. 25.07 WN showing an abrupt transition from the instrument shank to its tip (arrows); Surface finishing was irregular for WP and WN files, and polished for BR instruments $(*)$. (B) WP instrument flutes presented flattened cutting edges $(\Delta)$ compared to $B R$ and $W N$ files, in which a sharp angle could be detected. (C) Intentional groove defects were found at the flutes of 30.08 WP files. Unintentional abrupt flute features could be detected along the instrument differing from 25.07 WN and 25.08 BR instruments ( $\star$ ). BR files presented a well-defined and polished outline

\section{Discussion}

The present study analyzed the centering ability of two recently introduced NiTi rotary systems (WP and $\mathrm{WN}$ ), in comparison to an already established system (BR). The results observed herein showed that, generally, BR, WP, and WN instruments produced similar canal transportation, which was also comparable with the amount of deviation produced by other commonly employed rotary systems ${ }^{7,20}$. Recent studies have shown that NiTi files did not avoid the occurrence of apical transportation ${ }^{5,19,21}$, but this deviation is reduced when compared to manual techniques ${ }^{4,6,7}$.

Acceptable limits for canal transportation should be based on dental anatomical features. Thus, the measurement of canal wall thickness at different apical distances is of utmost importance when determining appropriate preparation techniques. In mesio-buccal roots of maxillary molars, dental walls are thicker toward the cervical portion.
Regarding mesiobuccal canals of maxillary molars, approximately $2 \mathrm{~mm}$ from the apex, root canal wall thickness is set between 0.84 and $2.15 \mathrm{~mm}$, whilst, at an apical distance of about $8 \mathrm{~mm}$, this measure is comprised between 1.23 and $1.58 \mathrm{~mm}^{22}$. Correlation among data presented suggests that all groups promoted tolerable canal transportation in most of the samples. Meanwhile, particularly for BR and WN groups at $2 \mathrm{~mm}$ from the apex, canal transportation was critical in some specimens if considering the possibility of iatrogenic complications. At this point, although not statistically significant, a potentially relevant advantage was detected for WP centering ability; this fact may be explained by greater WP file tapers, which were designed to provide further elimination of cervical interferences ${ }^{23}$.

A number of study models have been used to compare canal shape before and after instrumentation $^{5-7,9,12,21,24,25}$. However, taken into account the importance of dental tissue hardness and the morphological complexity cited above, curved roots 
of human molars were preferred ${ }^{26}$. Moreover, to avoid the influence of confounding factors, groups were balanced for variations in canal anatomy, as recommended ${ }^{16}$.

As well as previous studies ${ }^{5,7,16,19,21}$, this investigation used CBCT images to assess the centering ability of different instruments. Besides being a non-destructive and accurate method, this technique allows observation in both $\mathrm{MD}$ and $\mathrm{BP}$ directions, which is not possible when applying conventional radiographs ${ }^{27}$. Endodontic literature has yet to clearly establish an association between canal curvature and transportation directions. Whereas, some studies using mesiobuccal canals showed tendency toward mesial transportation ${ }^{19,25}$, which has been attributed to curvatures frequently observed in a distal positions. Meanwhile, other authors have stated that the direction of canal curvature has no effect on the direction of transportation ${ }^{28}$. One possible explanation for conflicting results is that methods employed no longer assessed the discrepancies between MD and BP transportation. The methodology adopted herein allowed such an approach, showing similar canal transportation in both directions.

Giannastasio et al. ${ }^{16}$ (2013) evaluated the apical transport of two rotary systems, Wizard CD Plus and Protaper Universal, in simulated root canals. The authors used the same subtraction technique and found that both systems promoted little apical transport with no statistically significant difference between them. Their findings are in agreement with those of the present study.

In this study, BR instruments presented a regular and polished surface when observed by SEM. In accordance with Yamazaki-Arasaki et al. ${ }^{15}$ (2013), BioRaCe and ProTaper instruments presented less roughness than other systems. On the other hand, WP and WN instruments showed irregular edges under SEM. These features were tactilely perceived by the friction during instrumentation, and could affect the canal centering ability, thus producing greater transportation in one direction. Nevertheless, irregularities in WP and WN groups may yet have contributed to such poor standardization of centering ability, which was supported by the high standard deviations observed.

However, despite differences in the topography of such instruments, no statistically significant difference between groups was observed. The basic sets recommended by the manufacturer were used for the preparation of root canals in this study, however, the apical instrument in the BR group was 40.04, and for the WP and WN groups it was 30.06 . The larger apical diameter presented by BR instruments could have negatively influenced the centralization of preparation. Such a hypothesis was not confirmed in this study because this system showed similar results of others systems. The fact that this group presents a regular surface might have influenced these results. Considering that in the present study a single use was established for the instruments, further studies are necessary to assess the influence of repeated uses on centering ability.

\section{Conclusion}

Taking into account the small dimensions of root canal walls, it can be concluded that none of the NiTi rotary instruments presented ideal centering ability, despite the differences in the topography of such instruments.

\section{Resumo}

Objetivo: Este estudo teve como objetivo avaliar a centralização do preparo e a topografia dos instrumentos BioRaCe ${ }^{\circledast}(B R)$, Wizard CD Plus ${ }^{\circledast}(W P)$ e Wizard Navigator $^{\circledast}(W N)$. Materiais e método: raízes mesio-vestibulares de primeiros molares superiores foram selecionadas e distribuídas aleatoriamente em três grupos $(n=10)$, de acordo com o sistema rotatório utilizado para a instrumentação. O transporte do canal foi avaliado a 2, 4 , 6 e $8 \mathrm{~mm}$ do vértice radicular, por meio de subtração de imagens de tomografia computadorizada de feixe cônico (TCFC), obtidas antes e depois do preparo. O centro do canal radicular foi marcado em imagens pré e pós- preparo, e a distância entre estes pontos foi medida nas direções vestíbulo-palatina (VP) e mésio-distal (MD). Instrumentos novos foram analisados sob microscopia eletrônica de varredura (MEV) em relação ao seu acabamento superficial, características topográficas e defeitos superficiais. As imagens em MEV foram obtidas na ponta do instrumento e a $5 \mathrm{~mm}$ da ponta. Os dados de centralização do preparo foram analisados por ANO$V A$ de dois critérios $(\alpha=0,05)$. Resultados: independentemente do nível radicular (2, 4, 6 e $8 \mathrm{~mm})$, todos os grupos apresentaram transporte do canal em ambas as direções. Diferenças significativas não foram detectadas ( $p>0,05)$. O acabamento superficial foi regular no grupo BR com o ângulo de transição sendo arredondado. As arestas de corte apresentaram um ângulo agudo nos grupos BR e WN, enquanto os instrumentos WP possuíam um ângulo achatado. Conclusão: apesar de tais diferenças topográficas entre os instrumentos rotatórios testados, nenhum deles foi capaz de manter exatamente o centro original do canal radicular, e não foram observadas diferenças significativas entre os grupos.

Palavras-chave: Preparo do canal radicular. Endodontia. Microscopia eletrônica de varredura. Instrumentos rotatórios. 


\section{References}

1. Auerbach MB. Factors for successful pulp canal therapy. NY Univ J Dent 1948; 6:213-6.

2. Schilder H. Cleaning and shaping the root canal. Dent Clin North Am 1974; 18:269-96.

3. Peters OA. Current challenges and concepts in the preparation of root canal systems: a review. J Endod 2004; 30:559-67.

4. Hulsmann M, Peters OA, Dummer PMH. Mechanical preparation of root canals: shaping goals, techniques and means. Endod Topics 2005; 10:30-76.

5. Hartmann MS, Barletta FB, Camargo Fontanella VR, Vanni JR. Canal transportation after root canal instrumentation: a comparative study with computed tomography. J Endod $2007 ; 33: 962-5$

6. Lopez FU, Fachin EV, Camargo Fontanella VR, Barletta FB, So MV, Grecca FS. Apical transportation: a comparative evaluation of three root canal instrumentation techniques with three different apical diameters. J Endod 2008; 34:1545-8.

7. Gergi R, Rjeily JA, Sader J, Naaman A. Comparison of canal transportation and centering ability of twisted files, Pathfile-ProTaper system, and stainless steel hand K-files by using computed tomography. J Endod 2010; 36:904-7.

8. Schafer E, Tepel J, Hoppe W. Properties of endodontic hand instruments used in rotary motion. Part 2. Instrumentation of curved canals. J Endod 1995; 21:493-7.

9. Chan AW, Cheung GS. A comparison of stainless steel and nickel-titanium K-files in curved root canals. Int Endod J 1996; $29: 370-5$

10. Troian CH, So MV, Figueiredo JA, Oliveira EP. Deformation and fracture of $\mathrm{RaCe}$ and $\mathrm{K} 3$ endodontic instruments according to the number of uses. Int Endod J 2006; 39:616-25.

11. Kuhn G, Tavernier B, Jordan L. Influence of structure on nickel-titanium endodontic instruments failure. J Endod $2001 ; 27: 516-20$

12. Bonaccorso A, Cantatore G, Condorelli GG, Schafer E, Tripi TR. Shaping ability of four nickel-titanium rotary instruments in simulated S-shaped canals. J Endod 2009; 35:883-6.

13. Lopes HP, Elias CN, Vieira VT, Moreira EJ, Marques RV, de Oliveira JC, et al. Effects of electropolishing surface treatment on the cyclic fatigue resistance of BioRace nickel-titanium rotary instruments. J Endod 2010; 36:1653-7.

14. Yamazaki-Arasaki A, Cabrales R, Santos M, Kleine B, Prokopowitsch I. Topography of four different endodontic rotary systems, before and after being used for the 12th time. Microsc Res Tech 2012; 75:97-102.

15. Yamazaki-Arasaki AK, Cabrales RJ, Kleine BM, Araki AT, Dos Santos M, Prokopowitsch I. Qualitative analysis of files of four different rotary systems, before and after being used for the twelfth time. Microsc Res Tech 2013; 76:79-85.

16. Giannastasio D, Rosa RA, Peres BU, Barreto MS, Dotto GN, Kuga MC, et al. Wizard CD Plus and ProTaper Universal: analysis of apical transportation using new software. J Appl Oral Sci 2013; 21:468-74.

17. Schneider SW. A comparison of canal preparations in straight and curved root canals. Oral Surg Oral Med Oral Pathol 1971; 32:271-5.
18. Dummer PM, Alodeh MH, Doller R. Shaping of simulated root canals in resin blocks using files activated by a sonic handpiece. Int Endod J 1989; 22:211-5.

19. Oliveira CA, Meurer MI, Pascoalato C, Silva SR. Cone-beam computed tomography analysis of the apical third of curved roots after mechanical preparation with different automated systems. Braz Dent J 2009; 20:376-81.

20. Baumann MA, Roth A. Effect of experience on quality of canal preparation with rotary nickel-titanium files. Oral Surg Oral Med Oral Pathol Oral Radiol Endod 1999; 88:714-8.

21. Tasdemir T, Aydemir H, Inan U, Unal O. Canal preparation with Hero 642 rotary Ni-Ti instruments compared with stainless steel hand K-file assessed using computed tomography. Int Endod J 2005; 38:402-8.

22. Degerness RA, Bowles WR. Dimension, anatomy and morphology of the mesiobuccal root canal system in maxillary molars. J Endod 2010; 36:985-9.

23. Medin. Rotary instruments for dentistry [catalog online]. NovéMěsto at Moravě: Czech Republic; 2011. [cited 2014 March 18]. Available from URL: http://www.medin.eu/rootinstruments-pa1121-m/

24. Schafer E, Vlassis M. Comparative investigation of two rotary nickel-titanium instruments: ProTaper versus RaCe. Part 1. Shaping ability in simulated curved canals. Int Endod J 2004; 37:229-38

25. Al-Sudani D, Al-Shahrani S. A comparison of the canal centering ability of ProFile, K3, and RaCe Nickel Titanium rotary systems. J Endod 2006; 32:1198-201.

26. Somma F, Leoni D, Plotino G, Grande NM, Plasschaert A. Root canal morphology of the mesiobuccal root of maxillary first molars: a micro-computed tomographic analysis. Int Endod J 2009; 42:165-74.

27. Goldberg F, Araujo JA. Comparison of three instruments in the preparation of curved root canals. Endod Dent Traumatol 1997; $13: 265-8$

28. Kosa DA, Marshall G, Baumgartner JC. An analysis of canal centering using mechanical instrumentation techniques. J Endod 1999; 25:441-5.

\section{Corresponding author:}

Renata Dornelles Morgental

Av. Itaqui, 701/201

90460-140 Porto Alegre / RS - Brazil

Phone: 555133318204

E-mail: remorgental@hotmail.com

Recebido: 08/10/2013. Aceito: 02/02/2014. 